\title{
The COVID-19 from Neurological Overview
}

Nörolojik Bakış Açısından COVID-19

(1) Şerefnur Öztürk

Head of the Turkish Neurological Society, Selcuk University Faculty of Medicine, Department of Head of Neurology, Konya, Turkey

After the Coronavirus disease-19 (COVID-19) outbreak was accepted as a pandemic with the statement made by the World Health Organization, the world medical oganizations, together with our Ministry of Health, started to make statements about the prevalence of the disease, its symptoms, methods of diagnosis, prevention, and treatment approaches. As the data on the pandemic have increased, the effects of the disease on other systems have begun to be understood. The place and importance of the neurologist in the more accurate and effective management of this disease process has been emphasized. In particular, studies to increase information on this subject and to explain possible mechanisms for the detection of neurologic findings have been the focus of attention $(1,2,3,4,5)$. The World Federation of Neurology, the European Academy of Neurology (EAN), and the American Academy of Neurology are publishing reports on their web sites on the neurologic findings that may arise from COVID-19 and prevention and treatment approaches in the COVID-19 era in neurologic diseases $(6,7,8,9)$. As the Turkish Neurological Society (TNS), we try to provide necessary information support to our members and patients in the light of current scientific data (10).

In this process in our country, the TNS COVID-19 Commission was established under the presidency of Prof. Şerefnur Öztürk and Prof. Mehmet Akif Topçuoğlu in order to provide accurate and effective information to the field of science about COVID-19 and its neurologic signs and symptoms, the most frequently reported arterial and venous thrombosis, and cerebrovascular disease conditions associated with COVID-19, central and peripheral nervous system disorders caused by the direct neurotrophic effects of the SARS-CoV-2 virus, the management of neurologic disorders during the pandemic, the approach to treatment in neurologic disorders that develop with COVID-19, and in order to support the necessary organizations, support our members who have been in need, and cooperate with them. This commission, which consisted of a large number of our colleagues, aimed to provide information on COVID-19 and neurology, to create and implement studies and projects, and to prepare and support a national database. The survey, which was prepared by the EAN COVID-19 Task Force and implemented by the EAN in this process, attracted interest from our members. In order to obtain data on the frequency and characteristics of neurologic symptoms of COVID-19 in Turkey, a multicenter TNS-COVID-19 digital-online registry was created and it started data retrieval (11). One of the most important studies conducted by our committee was the publishing of a very comprehensive review in The Turkish Journal of Neurology with the contribution of 30 authors. It was entitled "COVID-19 from a Neurological Overview" and prepared for neurologists and other disciplines to raise awareness and knowledge about the management of the process, and the effects of the COVID-19 pandemic on monitoring and treatment of neurologic diseases, in addition to the neurologic effects of COVID-19 (12). It has been shared with many disciplines affected by the COVID-19 pandemic across the country. We hope that it will be useful to all neurologists and all our colleagues who are interested in the subject. Current and future neurologic effects of the COVID-19 pandemic should be closely monitored and research on this subject should be supported.

\section{References}

1. Öztürk Ş. Covid-19 and Neurology. Turk J Neurol. Doi:10.4274/ tnd.2020.73384.

2. Román GC, Reis J, Spencer PS, et al. COVID-19 international neurological registries. Lancet Neurol 2020;19:484-485.

3. Sellner J, Taba P, Öztürk S, Helbok R. The need for neurologists in the care of COVID-19 patients. Eur J Neurol 2020. Doi:10.1111/ene.14257.

4. Román GC, Spencer PS, Reis J, et al. The neurology of COVID-19 revisited: A proposal from the Environmental Neurology Specialty Group of the World Federation of Neurology to implement international neurological registries. J Neurol Sci. 2020. Doi: 10.1016/j.jns.2020.116884.

5. Román GC, Reis J, Spencer PS, et al. COVID-19 international neurological registries. Lancet Neurol 2020. Doi: 10.1016/S1474-4422(20)30148-4.

Address for Correspondence/Yazışma Adresi: Şerefnur Öztürk MD, Head of the Turkish Neurological Society, Selcuk University Faculty of Medicine, Department of Head of Neurology, Konya, Turkey

Phone: +90332 2244010 E-mail: serefnur.ozturk@noroloji.org.tr ORCID: orcid.org/0000-0001-8986-155X

Received/Geliş Tarihi: 17.07 .2020 Accepted/Kabul Tarihi: 17.07 .2020

${ }^{\odot}$ Copyright 2020 by Turkish Neurological Society

Turkish Journal of Neurology published by Galenos Publishing House. 
6. World Federation of Neurology (WFN). Access Date: July 2020. Available from:https://wfneurology.org/covid-19-and-world-neurology\#bulletin-board

7. European academy of neurology (Ean). Access Date: July 2020. Available from: https://www.ean.org/CME.2714.0.html

8. European academy of neurology (Ean). Access Date: July 2020. Available from: https://www.ean.org/Recommendations-Guidelines.4326.0.html

9. American Academy of Neurology (AAN). Access Date: July 2020 Available from: www.aan.com/tools-and-resources/covid-19-neurology-resource-center/
10. Türk Nöroloji Derneği. Access Date: July 2020, Available from: https:// www.noroloji.org.tr/menu/158/covid-19-bilgi

11. Türk Nöroloji Derneği. Access Date: July 2020. Available from: https://www. noroloji.org.tr/menu/160/covid-19-ve-noroloji-konusunda-planlanmis-olancalismalar

12. Acar T, Acıman Demirel E, Afşar N, et al. The COVID-19 Pandemic and Neurology. Turk J Neurol 2020;26. Doi:10.4274/tnd.2020.73669. 